\title{
SUPERIOR LINES FOR AGRO-TECHNOLOGICAL TRAITS IN SAFFLOWER (Carthamus tinctorius L.)
}

\author{
Ebru ASKIN ${ }^{l}$, Sabri ERBAS ${ }^{* 2}$ \\ ${ }^{1}$ Ministry of Agriculture and Forestry, Denizli, TURKEY \\ ${ }^{2}$ Isparta University of Applied Sciences, Faculty of Agriculture, Department of Field Crops, Isparta, \\ TURKEY \\ *Corresponding authors: sabrierbas@isparta.edu.tr
}

Received: 29.01 .2020

\begin{abstract}
In safflower (Carthamus tinctorius L.) breeding, determining superior pure lines after crossing for agrotechnological traits is the first step to improve new cultivar candidates. Therefore, aim of the study was to determine superior pure lines of sufflower in $F_{9-10}$ derived three intraspecific crosses evaluating the agronomical and technological (quality) traits. A total of 25 safflower genotypes including 15 pure lines was compared with 10 standard cultivars (Dincer 5-18-1, Centennial, Remzibey-05, Balci, Linas, Olas, Gelendost-2, Gokturk, Montola 2000 and W6 9822) and genotypes along with parents of lines for two years in 2017-2018. GEMO-20 had higher 1000-seed weight, GECE-8 and GEMO-20 had higher oil content, GEMO-19, 28 and GEW6-7 had higher oil yield, GEMO-28 and GEW6-7 had higher seed yield than standard cultivars. According to 1000-seed weight, oil content, seed and oil yield traits, GEMO-19, GEMO-20, GEMO-28 and GEW6-7 lines were identified as superior lines.
\end{abstract}

Keywords: Advanced lines, Carthamus tinctorius, quality traits, safflower, yield and yield traits

\section{INTRODUCTION}

Worldwide 691.000 tons of safflower (Carthamus tinctorius L.) seed is produced in an area of 841.000 ha. Approximately $95 \%$ of world's safflower production is in Kazakhstan, Kyrgyzstan, India, USA, Mexico and China (FAOSTAT, 2020). Safflower is sown in area of 27.376 ha and produced 50.000 tons with average seed yield of $1830 \mathrm{~kg}$ per ha in Turkey (FAOSTAT, 2020). Turkey, for many years, has imported oilseeds and vegetable crude oil resulted in a large trade deficit. Although the annual oil seed production of Turkey was 3.4 million tons in 2017, oil seeds, vegetable oil and oil-cakes of 8.5 million tons was imported by Turkey, which was comprised of 3.7 million tons of oil seeds ( $\$ 1.6$ billion), 1.3 million tons of crude oil ( $\$ 1.05$ billion), and 3.5 million tons of oil-cakes ( $\$ 837$ million), at a total cost of $\$ 3.5$ billion (BYSD, 2020).

Central Anatolian, south-eastern Anatolian and eastern Anatolian regions are the arid and semi-arid agricultural lands of Turkey. If safflower, legumes and cereals are included in the rotation system in these areas especially in fallowlands, safflower can be an important alternative oil source in closing increasing oil deficit (Erbas and Baydar, 2007). In the last five years, the unforeseen decrease in safflower cultivation is attributed to the low seed yield (average 1500 and $2000 \mathrm{~kg}$ per ha in dry and irrigated conditions, respetively) and low level oil ratio of $25-35 \%$ (Erbas, 2012). Therefore, improvement to new safflower varieties with high seed yield and oil content, low hull content and rich in oleic and linoleic acids are the primary goals and achieving these goals depends on the application of alternative cultivation and breeding methods that will improve seed and oil yield and better cope with biotic and abiotic stressors (Weiss, 2000; Singh et al., 2008; Golkar and Shahsavari, 2011).

Although sufflower is mostly a cross pollinated crop, pedigree selection method is generally used to improve new cultivars. In addition to the pedigree method, a single seed descent method and modified bulk selection can also be used. In this method, from $\mathrm{F}_{2}$ to pure lines in $\mathrm{F}_{6}$, a single seed or a head of all hybrid plants is bulked and grown without using any selection. Thus, natural selection of lines is allowed to function each year. Pure lines after $\mathrm{F}_{6}$ are compared with standard varieties in micro and macro experimets. According to results of these experiments, superior lines showing higher performance based on adaptation and stability abilities can be evaluated as candidate cultivars (Weiss, 2000; Rudra Naik et al., 2009; Baydar et al., 2011).

Many of the safflower varieties registered in Turkey have been developed by simple bulk or single selection methods without resorting to hybridization from 
genetically diverse populations or introduction materials. However, safflower varieties with high commercial value in the world are widely developed with hybridization breeding (Baydar and Erbas, 2016) and this number should be increased in Turkey for safflower breeding purposes. The study was aimed to determine superior pure lines of sufflower in $\mathrm{F}_{9-10}$ derived three intraspecific crosses evaluating the agronomical and technological (quality) characteristics.

\section{MATERIALS AND METHODS}

Field trials of this research were conducted in Department of Field Crops, Faculty of Agriculture, Isparta Applied Sciences University, Isparta province $\left(37^{\circ} 45^{\prime} \mathrm{N}\right.$ and $30^{\circ} 33^{\prime} \mathrm{E}, 997 \mathrm{~m}$ ) in 2017 and 2018. F9-10 lines derived from intraspecific crosses by using synthetic male sterility [five lines of Gelendost- $2 \times$ Centennial, seven lines of Gelendost- $2 \times$ Montola 2000 and three lines of Gelendost-2 $\times$ W6 9822] and 10 safflower cultivars/lines (Dincer 5-18-1, Centennial, Remzibey-05, Balci, Linas, Olas, Gelendost-2 (line), Gokturk, Montola 2000 and W6 9822 (line)) were used as materials. Soil characteristics of the research area were assessed according to the method proposed by Rowell (1996). The soil texture was clay loam; lime was $7.2 \%$ by Schiebler calcimeter; the organic matter was $1.1 \%$ by the Walkley-Black method; exchangeable $\mathrm{K}$ was $119 \mathrm{mg} \mathrm{kg}^{-1}$ by $1 \mathrm{~N} \mathrm{NH}_{4} \mathrm{OAc}$; total salt was $0.38 \%$; the $\mathrm{pH}$ in a soil saturated extract was 7.5 and extractable $\mathrm{P}$ was $3.9 \mathrm{mg} \mathrm{kg}^{-1}$ by $0.5 \mathrm{~N} \mathrm{NaHCO}_{3}$ extraction. The total precipitation, mean humidity, minimum and maximum temperatures and long term averages for the experimental area were given in Table 1. When the climate data are analyzed, there was not very high or low temperature and precipitation during the vegetation period (March-August) that would seriously affect the normal growth and development of the plants. In $2017,254.8 \mathrm{~mm}$ of total precipitation fell from the sowing of seeds to the flowering time of the plants (beginning of March-end of June), while it was $207.9 \mathrm{~mm}$ of precipitationin in 2018 . On the other hand, $25.6 \mathrm{~mm}$ of precipitation was falling in April 2017; the amount of precipitation was $6.3 \mathrm{~mm}$ in 2018. During the seed maturing period, a difference of $0.9^{\circ} \mathrm{C}$ in July and $0.5^{\circ} \mathrm{C}$ in August are observed in both experimental years.

Table 1. The climate data of Isparta for long years and 2017-2018 (Anonymous, 2020)

\begin{tabular}{|c|c|c|c|c|c|c|c|c|c|c|c|c|c|}
\hline \multirow{3}{*}{ Month } & \multicolumn{4}{|c|}{ Total Precipitation, $\mathrm{L} \mathrm{m}^{2}$} & \multicolumn{6}{|c|}{ Mean temperature, ${ }^{\circ} \mathrm{C}$} & \multicolumn{3}{|c|}{ Mean humidity, \% } \\
\hline & \multirow{2}{*}{$\begin{array}{c}1950- \\
2018\end{array}$} & \multirow{2}{*}{2017} & \multirow{2}{*}{2018} & \multirow{2}{*}{$\begin{array}{c}1950- \\
2018\end{array}$} & \multicolumn{3}{|c|}{2017} & \multicolumn{3}{|c|}{2018} & \multirow{2}{*}{$\begin{array}{l}1950- \\
2018\end{array}$} & \multirow{2}{*}{2017} & \multirow{2}{*}{2018} \\
\hline & & & & & Min. & Max. & Mean & Min. & Max. & Mean & & & \\
\hline March & 57.3 & 74.4 & 69.3 & 6.1 & -4.4 & 21.8 & 7.3 & -1.6 & 20.4 & 9.2 & 65.6 & 64.1 & 65.9 \\
\hline April & 51.6 & 25.6 & 6.3 & 10.7 & -0.9 & 25.5 & 10.6 & 0.0 & 28.3 & 14.2 & 60.8 & 59.6 & 51.0 \\
\hline May & 55.7 & 149.5 & 62.9 & 15.2 & 4.0 & 31.9 & 14.9 & 5.8 & 29.6 & 16.8 & 58.7 & 63.7 & 62.3 \\
\hline June & 32.6 & 30.9 & 69.4 & 19.8 & 6.6 & 35.8 & 20.1 & 10.3 & 32.6 & 20.0 & 52.1 & 58.9 & 62.4 \\
\hline July & 16.5 & 13.1 & 4.1 & 23.3 & 13.8 & 38.6 & 25.2 & 12.6 & 34.3 & 24.3 & 45.4 & 41.9 & 46.9 \\
\hline August & 13.4 & 20.4 & 14.2 & 23.1 & 12.1 & 36.9 & 23.8 & 12.1 & 34.4 & 24.3 & 46.3 & 52.1 & 47.6 \\
\hline & 227.1 & 313.9 & 226.2 & 16.4 & 5.2 & 31.8 & 17.0 & 6.5 & 29.9 & 18.1 & 54.8 & 56.7 & 56.0 \\
\hline
\end{tabular}

The lines and cultivars were evaluated in a randomized complete block design with three replications. Seeds of lines and cultivars were sown by hand on March 29 and 27, 2017 and 2018, respectively. Sowing norm was $0.50 \times$ $0.15 \mathrm{~m}$. The plot length was $5 \mathrm{~m}$ and each plot contained 5 rows. Experimental areas were fertilized with $8 \mathrm{~kg} \mathrm{da}^{-1}$ of $\mathrm{P}$ [diammonium phosphate $(18 \% \mathrm{~N}, 46 \% \mathrm{P})$ ] and $10 \mathrm{~kg}$ $\mathrm{da}^{-1}$ of $\mathrm{N}$ [ammonium nitrate $(33 \% \mathrm{~N})$ ]. Weed control was performed by mechanical rotary tillage and manual weeding. Experimental areas were not irrigated. The lines and cultivars were harvested on the last week of August in both years and the three middle rows except for outer rows of the plot were harvested by hand. Agronomic characters such as plant height $(\mathrm{cm})$, branches number (no plant $^{-1}$ ), head number (no plant $\left.{ }^{-1}\right)$, head diameter $(\mathrm{mm})$, harvest index $(\%), 1000$ seed weight $(\mathrm{g})$ and seed yield $\left(\mathrm{kg} \mathrm{da}^{-1}\right)$, quality characters such as hull content $(\%)$, oil content $(\%)$, oil yield $\left(\mathrm{kg} \mathrm{da}^{-1}\right)$, and fatty acid composition (\%) examined in 10 randomly selected plants.

The oil content and fatty acid composition were analyzed by Nuclear magnetic resonance (NMR, Bruker, the USA) and Gas chromatography (GC-FID, Shimadzu GC-2025, Japan), respectively. For the analysis of oil content, seeds were oven-dried in a ventilated oven at $35^{\circ} \mathrm{C}$ for 2 days until reaching constant moisture content and the oil content of $2.0 \mathrm{~g}$ of seed was detected in NMR. For analyze the fatty acid composition, the oil extracted with $n$-hexane from the seeds and oil was converted to its fatty acid methyl esters (Marquard, 1987). The methyl esters of the fatty acids $(1.0 \mu \mathrm{l})$ were analyzed in a GC equipped with a flame ionizing detector (FID) and a fused silica capillary column [TR-CN100 $(100 \mathrm{~m} \times 0.25 \mathrm{~mm}$, $0.20 \mu \mathrm{m})$ ]. A GC-FID analysis was performed as follows: the oven temperature was kept at $140^{\circ} \mathrm{C}$ for $10 \mathrm{~min}$ and programmed to $240^{\circ} \mathrm{C}$ at a rate of $3^{\circ} \mathrm{C} \min ^{-1}$ and then constant at $240^{\circ} \mathrm{C}$ for $10 \mathrm{~min}$; total running time: $65 \mathrm{~min}$; injector temperature: $250^{\circ} \mathrm{C}$; detector $(70 \mathrm{eV})$ temperature: $250^{\circ} \mathrm{C}$; the flow rate for nitrogen: $40 \mathrm{ml} \mathrm{min}^{-}$

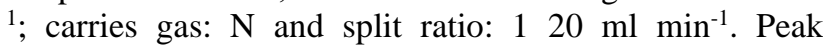
identification was conducted by comparing the relative retention times with those of a commercial standard mix of fatty acid methyl esters (Sigma, Supelco ${ }^{\circledR} 37$ Component FAME Mix). The contents of palmitic $\left(\mathrm{C}_{16: 0}\right)$, stearic $\left(C_{18: 0}\right)$, oleic $\left(C_{18: 1}\right)$, and linoleic $\left(C_{18: 2}\right)$ acid were determined. All data were analyzed using GLM producers of SAS (1999) and means were compared using Duncan Multiple Range Test at the probability level of 0.05 .

\section{RESULTS AND DISCUSSION}


According to the results combined ANOVA, the differences among the years (except for head number, harvest index and oil yield), genotypes and year $x$ genotype (except for harvest index, seed yield, oil content and oil yield) were significant $(\% 1)$ for all characteristics (Table 2).

Table 2. The ANOVA results of variance on the agronomic and quality characteristics of safflower genotypes.

\begin{tabular}{|c|c|c|c|c|c|c|c|c|c|c|c|}
\hline $\begin{array}{l}\text { Sources } \\
\text { of } \\
\text { variance }\end{array}$ & Df & $\begin{array}{l}\text { Plant } \\
\text { height }\end{array}$ & $\begin{array}{c}\text { Branches } \\
\text { number }\end{array}$ & $\begin{array}{c}\text { Head } \\
\text { number }\end{array}$ & $\begin{array}{c}\text { Head } \\
\text { diameter }\end{array}$ & $\begin{array}{c}1000 \\
\text { seed } \\
\text { weight }\end{array}$ & $\begin{array}{c}\text { Harvest } \\
\text { index }\end{array}$ & $\begin{array}{c}\text { Hull } \\
\text { content }\end{array}$ & $\begin{array}{l}\text { Seed } \\
\text { yield }\end{array}$ & $\begin{array}{c}\text { Oil } \\
\text { content }\end{array}$ & $\begin{array}{c}\text { Oil } \\
\text { yield }\end{array}$ \\
\hline Year (Y) & 1 & $1416.8 * * a$ & $313.3 * *$ & 2.8 & $38.1 * *$ & $669.1 * *$ & 1.4 & $248.3 * *$ & $2423.3 * *$ & $77.6 * *$ & 31.5 \\
\hline Block $\times$ Y & 4 & 21.3 & 1.1 & 2.9 & 1.0 & 2.6 & 7.0 & 1.4 & 95.9 & 3.4 & 24.5 \\
\hline $\begin{array}{l}\text { Genotype } \\
\text { (G) }\end{array}$ & 24 & $272.9 * *$ & $11.4 * *$ & $55.4 * *$ & $7.6^{* *}$ & $55.3 * *$ & $103.0 * *$ & $50.3 * *$ & $5217.3 * *$ & $37.6 * *$ & $506.1^{* *}$ \\
\hline Y x G & 24 & $68.1 * *$ & $5.1 * *$ & $21.2 * *$ & $3.8 * *$ & $13.6^{* *}$ & 1.4 & $15.3 * *$ & 70.5 & 0.6 & 5.4 \\
\hline Error & 96 & 16.8 & 1.1 & 2.3 & 1.6 & 5.6 & 3.4 & 4.3 & 146.0 & 0.5 & 15.7 \\
\hline $\mathrm{CV}(\%)$ & & 5.3 & 14.0 & 11.5 & 5.9 & 6.3 & 12.0 & 4.3 & 10.5 & 2.2 & 10.7 \\
\hline
\end{tabular}

a, mean squares of characters ; Df, degree of freedom; CV, coefficient of variation; $* * \mathrm{p}<0.01$

The average plant height of safflower genotypes in 2017 was longer than in 2018. It is thought that the differences in temperature and rainfall caused the plants grown in 2018 to be shorter. The heritability of plant height in safflower is low and can be easily affected by environmental conditions due to additive effective genes (Ramachandram and Goud, 1981). According to year $\times$ genotype interaction, the longest plant height genotype was Gelendost-2 in both years, the shortest genotypes were W6 9822 in 2017, W6 9822, GEMO-1, Centennial, Gokturk, GEMO-10 and Remzibey-05 in 2018. Weiss (2000) is reported that plant height should be 55.0-65.0 $\mathrm{cm}$ both in terms of suitability to machine harvest and in order to obtain an economic yield. The plant height of the genotypes in our study was found higher than these values. The main reason for this is that the Gelendost- 2 genotype, which is one of the parents of hybrid lines, was high and it may be due to its transmission of this feature to hybrid offspring. The number of branches per plant ranged from 4.1 to 12.4 in the study. During the vegetation period, the number of branches of genotypes was higher in 2017 plants. These differences may be caused by environmental factors. The precipitation's in seed rowing and budding period was higher in 2017. In 2018, due to the high temperatures observed during this period, the plants may have quickly budded and formed fewer branches. The number of branches of safflower was a feature affected by genotype $\times$ environment interaction (Singh et al., 2008). According to the year $\times$ genotype interaction; Balci, GEMO-23, Gokturk, Remzibey-05, Olas, Linas and GEMO-28, genotypes to the highest number of branches in 2017, GEMO-3 in 2018. Weiss (2000) emphasized that 6 to 8 branches should be available in the plant for economic safflower production. However, some researchers reported that the number of branches might increase up to 50 in safflower (Deokar and
Patil, 1980). Our results were found within the limits reported by these researchers.

The number of head per plant ranged from 7.8 to 24.6 in the study. GEMO-19 genotype was the most head number in 2017, GEMO-3, 19 and Balci genotypes in 2018. The least number of tables was determined in 7 genotypes in 2017 and 5 genotypes in 2018. The environmental factors on the head number in safflower, genotypes were reported to be effective in the genetic structure. However, although the head number of safflower has been reported to have a moderate and high inheritance, it is reported that variations can occur when genotypes with the same genetic structure are grown in different locations (Parameshwar, 2009). In our country, it was reported that the head number in safflower varies according to years, location and genetic resources (Beyyavas et al., 2010; Ada, 2012; Adali and Ozturk, 2016). The differences between our results and other studies may be due to the fact that our genotypes show genetic differences and the climate characteristics are different. Head diameter was not directly related to seed yield in safflower, but affects seed yield on seed number per head and 1000 seed weight. The average head diameter of the genotypes in $2017(21.6 \mathrm{~mm})$ was larger than in 2018 (20.6 mm). GEW6-16, GEMO-1 and Montola 2000 genotypes in 2017, GECE-4, 9, GEW6-7, 16, GEMO-28 and Montola 2000 genotypes in 2018 have the highest head diameter (Table 3). In our study, it was thought that the branches number is low and the table number is high because of the lack of rainfall during the rosette and bolting period in 2018. Because, the head diameter can be easily affected by the changing environmental conditions and may vary according to years (Camas and Esendal, 2006; Parameshwar, 2009; Erbas, 2012). 
Table 3. Agronomic and quality characteristics of safflower genotypes

\begin{tabular}{|c|c|c|c|c|c|c|c|c|c|c|c|c|c|c|c|c|c|c|}
\hline \multirow{2}{*}{ Genotypes } & \multicolumn{3}{|c|}{ Plant height } & \multicolumn{3}{|c|}{ Branches number } & \multicolumn{3}{|c|}{ Head number } & \multicolumn{3}{|c|}{ Head diameter } & \multicolumn{3}{|c|}{1000 seed weight } & \multicolumn{3}{|c|}{ Hull content } \\
\hline & 2017 & 2018 & Mean & 2017 & 2018 & Mean & 2017 & 2018 & Mean & 2017 & 2018 & Mean & 2017 & 2018 & Mean & 2017 & 2018 & Mean \\
\hline GECE 4 & $84.5 \mathrm{c}-\mathrm{g}^{1}$ & $83.1 \mathrm{~d}-\mathrm{h}$ & 83.8 & $6.9 \mathrm{k}-\mathrm{o}$ & $5.71-q$ & 6.3 & $9.4 \mathrm{o}-\mathrm{s}$ & $13.1 \mathrm{f}-\mathrm{m}$ & 11.3 & $21.6 \mathrm{~b}-\mathrm{i}$ & $21.9 \mathrm{~b}-\mathrm{i}$ & 21.8 & $34.51-\mathrm{s}$ & $40.3 \mathrm{~b}-\mathrm{j}$ & 37.4 & 46.4 i-r & $52.2 \mathrm{c}-\mathrm{f}$ & 49.3 \\
\hline GECE 8 & $7 \mathrm{~h}-\mathrm{p}$ & $80.0 \mathrm{~d}-\mathrm{k}$ & 77.9 & $51-p$ & $41-p$ & 6.5 & $9.3 \mathrm{o}-\mathrm{s}$ & $14.9 \mathrm{e}-\mathrm{i}$ & 12.1 & $21.2 c-j$ & $20.7 \mathrm{~d}-\mathrm{j}$ & 21.0 & $28.9 \mathrm{u}$ & $33.4 \mathrm{n}-\mathrm{t}$ & 31.2 & $43.1 \mathrm{q}-\mathrm{r}$ & 47.7 g-p & 45.4 \\
\hline GECE 9 & $4 \mathrm{~d}-\mathrm{i}$ & 75.8 h-p & 79.1 & $5 \mathrm{~h}-\mathrm{m}$ & 8 o-q & 6.1 & $9 \mathrm{p}-\mathrm{s}$ & $1.3 \mathrm{k}-\mathrm{q}$ & 10.1 & $21.0 \mathrm{c}-\mathrm{j}$ & $22.9 \mathrm{~b}-\mathrm{e}$ & 21.9 & $30.4 \mathrm{~s}-\mathrm{u}$ & $41.0 \mathrm{~b}-\mathrm{g}$ & 35.7 & 44.0 o-r & $47.7 \mathrm{~g}-\mathrm{p}$ & 45.9 \\
\hline GECE 11 & 8 e-1 & $87.3 \mathrm{c}-\mathrm{d}$ & 83.1 & $6.71-p$ & $4.7 \mathrm{pq}$ & 5.7 & $8.9 \mathrm{p}-\mathrm{s}$ & $8.4 \mathrm{q}-\mathrm{s}$ & 8.7 & $21.5 \mathrm{c}-\mathrm{i}$ & $20.1 \mathrm{f}-\mathrm{k}$ & 20.8 & $33.5 \mathrm{~m}-\mathrm{t}$ & $42.5 \mathrm{a}-\mathrm{d}$ & 38.0 & $47.2 \mathrm{~h}-\mathrm{q}$ & $50.4 \mathrm{c}-\mathrm{i}$ & 48.8 \\
\hline GECE 12 & $.5 \mathrm{c}-\mathrm{e}$ & $73.7 \mathrm{j}-\mathrm{p}$ & 80.1 & $7.6 \mathrm{~h}-1$ & $4.8 \mathrm{o}-\mathrm{q}$ & 6.2 & $9.2 \mathrm{p}-\mathrm{s}$ & $8.2 \mathrm{q}-\mathrm{s}$ & 8.7 & $21.3 c-j$ & $21.1 \mathrm{c}-\mathrm{j}$ & 21.2 & $35.9 \mathrm{i}-\mathrm{q}$ & $36.5 \mathrm{~g}-\mathrm{p}$ & 36.2 & $44.1 \mathrm{n}-\mathrm{r}$ & $53.5 \mathrm{~b}-\mathrm{d}$ & 48.8 \\
\hline GEMO 1 & $3.2 \mathrm{j}-\mathrm{p}$ & $64.5 \mathrm{rs}$ & 68.9 & $7.1 \mathrm{j}-\mathrm{n}$ & $4.1 \mathrm{q}$ & 5.6 & $10.3 \mathrm{~m}-\mathrm{s}$ & $7.8 \mathrm{~s}$ & 9.1 & $24.0 \mathrm{ab}$ & $20.1 \mathrm{f}-\mathrm{k}$ & 22.1 & $29.3 \mathrm{tu}$ & $31.9 \mathrm{p}-\mathrm{q}$ & 30.6 & $45.3 \mathrm{k}-\mathrm{r}$ & $47.1 \mathrm{~h}-\mathrm{r}$ & 46.2 \\
\hline GEMO 3 & $.3 \mathrm{~d}-\mathrm{k}$ & 75.7 h-p & 77.5 & $8.9 \mathrm{f}-\mathrm{k}$ & $9.1 \mathrm{e}-\mathrm{j}$ & 9.0 & 10.9 k-r & $19.7 \mathrm{~b}$ & 15.3 & $21.5 \mathrm{c}-\mathrm{i}$ & 17.31 & 19.4 & $35.1 \mathrm{k}-\mathrm{r}$ & $35.6 \mathrm{j}-\mathrm{q}$ & 35.4 & $52.9 \mathrm{~b}-\mathrm{e}$ & $50.8 \mathrm{c}-\mathrm{h}$ & 51.9 \\
\hline GEMO 10 & $1.4 \mathrm{i}-\mathrm{p}$ & $68.7 \mathrm{o}-\mathrm{s}$ & 71.5 & $9.3 \mathrm{~d}-\mathrm{i}$ & $6.51-p$ & 7.9 & $14.5 e-j$ & $16.3 \mathrm{c}-\mathrm{e}$ & 15.4 & $21.0 \mathrm{c}-\mathrm{j}$ & $17.9 \mathrm{kl}$ & 19.4 & $38.2 \mathrm{c}-\mathrm{m}$ & $36.2 \mathrm{~h}-\mathrm{q}$ & 37.2 & $47.9 \mathrm{~g}-\mathrm{o}$ & $51.6 \mathrm{c}-\mathrm{g}$ & 49.7 \\
\hline GEMO 19 & $1.7 \mathrm{i}-\mathrm{p}$ & $72.2 \mathrm{k}-\mathrm{r}$ & 73.5 & $10.0 \mathrm{~b}-\mathrm{f}$ & $7.4 \mathrm{I}-\mathrm{n}$ & 8.7 & $24.6 \mathrm{a}$ & $18.6 \mathrm{bc}$ & 21.6 & $20.7 \mathrm{~d}-\mathrm{j}$ & & 20.1 & $34.51-\mathrm{s}$ & $39.7 \mathrm{~b}-\mathrm{k}$ & 37.1 & 43.9 o-r & $43.7 \mathrm{pr}$ & 43.8 \\
\hline GEMO 20 & $3 \mathrm{~d}-\mathrm{i}$ & $79.4 \mathrm{~d}-\mathrm{k}$ & 81.1 & $9.7 \mathrm{~b}-\mathrm{g}$ & $6.01-q$ & 8.5 & $13.8 \mathrm{e}-\mathrm{k}$ & & 13.7 & $22.2 \mathrm{~b}-\mathrm{h}$ & $20.8 \mathrm{~d}-\mathrm{j}$ & 21.6 & $37.2 \mathrm{f}-\mathrm{n}$ & & 41.9 & $43.6 \mathrm{p}-\mathrm{r}$ & $49.6 \mathrm{~g}-\mathrm{j}$ & 46.6 \\
\hline 1023 & $6 \mathrm{e}-\mathrm{m}$ & $76.7 \mathrm{~g}-\mathrm{o}$ & 77.7 & $12.1 \mathrm{a}$ & $5.71-q$ & 8.9 & $20.3 \mathrm{~b}$ & & 17 & $22.9 \mathrm{~b}-\mathrm{e}$ & & 22.0 & $4 \mathrm{o}-\mathrm{u}$ & $f-n$ & 34.8 & $47.9 \mathrm{~g}-\mathrm{o}$ & $46.1 \mathrm{j}-\mathrm{r}$ & 47.0 \\
\hline & g-p & 71. & 74. & $11.0 \mathrm{a}-\mathrm{e}$ & & 8.8 & $e-i$ & & & $20.3 \mathrm{f}-\mathrm{k}$ & & 21.2 & $37.0 \mathrm{~g}-\mathrm{o}$ & & 38 & $45.3 \mathrm{k}-\mathrm{r}$ & g-o & 46.7 \\
\hline V6 7 & $0 j-p$ & $76.5 \mathrm{~g}-\mathrm{o}$ & 74.7 & $8.9 \mathrm{f}-\mathrm{k}$ & $5.4 \mathrm{~m}-\mathrm{q}$ & 7.2 & $10.7 \mathrm{l}-\mathrm{s}$ & $11.0 \mathrm{k}-\mathrm{r}$ & 10.8 & $23.1 \mathrm{~b}-\mathrm{d}$ & $21.8 \mathrm{~b}-\mathrm{i}$ & 22.5 & $36.8 \mathrm{~g}-\mathrm{o}$ & $40.7 \mathrm{~b}-\mathrm{h}$ & 38.7 & $48.5 \mathrm{f}-\mathrm{m}$ & 44.0 o-r & 46.3 \\
\hline GEW6 16 & $4 \mathrm{f}-\mathrm{m}$ & $80.9 \mathrm{~d}-\mathrm{j}$ & 79.6 & 7.7 h-1 & $4.7 \mathrm{pq}$ & 6.2 & $8.4 \mathrm{q}-\mathrm{s}$ & $9.8 \mathrm{n}-\mathrm{s}$ & 9.1 & $25.4 \mathrm{a}$ & $22.2 \mathrm{~b}-\mathrm{h}$ & 23.8 & $30.8 \mathrm{r}-\mathrm{u}$ & $39.3 \mathrm{c}-\mathrm{k}$ & 35.1 & $45.7 \mathrm{j}-\mathrm{r}$ & $45.3 \mathrm{k}-\mathrm{r}$ & 45.5 \\
\hline N6 20 & $3 \mathrm{~d}-\mathrm{i}$ & $72.0 \mathrm{k}-\mathrm{r}$ & 77.2 & $9.7 \mathrm{~b}-\mathrm{g}$ & $6.01-\mathrm{q}$ & 7.9 & $13.8 \mathrm{e}-\mathrm{k}$ & 11. & 12 & $22.2 \mathrm{~b}-\mathrm{h}$ & $20.8 \mathrm{~d}-\mathrm{j}$ & 21.5 & $31.6 \mathrm{q}-\mathrm{u}$ & $38.9 \mathrm{c}-1$ & 35 & $43.0 \mathrm{r}$ & $47.9 \mathrm{~g}-\mathrm{o}$ & 45.4 \\
\hline Dincer 5-18-1 & $.5 \mathrm{c}-\mathrm{f}$ & $70.71-r$ & 78.6 & $.5 \mathrm{c}-\mathrm{h}$ & $5.3 n-q$ & 7.4 & $4.6 e-j$ & $9.9 \mathrm{n}-\mathrm{s}$ & 12.2 & $21.1 \mathrm{c}-\mathrm{i}$ & $20.0 \mathrm{~g}-\mathrm{k}$ & 20.6 & $38.8 \mathrm{c}-1$ & $41.1 \mathrm{~b}-\mathrm{g}$ & 39.9 & $49.4 \mathrm{e}-\mathrm{k}$ & $49.0 \mathrm{e}-1$ & 49.2 \\
\hline Remzibey-05 & 74.0 j-p & $69.6 \mathrm{n}-\mathrm{s}$ & 71.8 & $11.5 \mathrm{ab}$ & $5.91-q$ & 8.7 & $15.8 \mathrm{e}-\mathrm{i}$ & $11.2 \mathrm{k}-\mathrm{q}$ & 13.5 & $18.8 \mathrm{j}-1$ & $20.2 \mathrm{f}-\mathrm{k}$ & 19.5 & 37.4 e-n & $42.9 \mathrm{a}-\mathrm{c}$ & 40.2 & $50.5 \mathrm{c}-\mathrm{i}$ & $49.7 \mathrm{~d}-\mathrm{j}$ & 50.1 \\
\hline Balci & $.3 \mathrm{~d}-\mathrm{k}$ & 74.4 i-p & 77.3 & $12.4 \mathrm{a}$ & $7.2 \mathrm{j}-\mathrm{n}$ & 9.8 & $14.6 e-j$ & $18.3 \mathrm{bc}$ & 16.5 & $19.4 \mathrm{i}-1$ & $19.7 \mathrm{~h}-\mathrm{k}$ & 19.6 & 37.5 e-n & $39.9 b-j$ & 38.7 & $45.21-\mathrm{r}$ & $47.2 \mathrm{~h}-\mathrm{q}$ & 46.2 \\
\hline Linas & $4.3 \mathrm{~b}$ & 75.8 h-p & 85.1 & $11.1 \mathrm{a}-\mathrm{d}$ & $7.8 \mathrm{~g}-1$ & 9.4 & $16.1 \mathrm{c}-\mathrm{f}$ & $13.2 \mathrm{f}-\mathrm{m}$ & 14.7 & 22.0 b-h & $20.6 \mathrm{~d}-\mathrm{j}$ & 21.3 & 40.4 b-i & $41.1 \mathrm{~b}-\mathrm{g}$ & 40.8 & $43.2 \mathrm{q}-\mathrm{r}$ & $50.8 \mathrm{c}-\mathrm{h}$ & 47.0 \\
\hline Olas & $.9 \mathrm{bc}$ & $72.5 \mathrm{k}-\mathrm{q}$ & 81.7 & $11.3 \mathrm{a}-\mathrm{c}$ & $5.9 \mathrm{l}-\mathrm{q}$ & 8.6 & $17.9 \mathrm{~b}-\mathrm{d}$ & $12.9 \mathrm{~g}-\mathrm{m}$ & 15.4 & $21.5 \mathrm{c}-\mathrm{i}$ & $21.0 \mathrm{c}-\mathrm{j}$ & 21.2 & $40.0 \mathrm{~b}-\mathrm{j}$ & $42.1 \mathrm{a}-\mathrm{d}$ & 41.1 & $43.3 \mathrm{q}-\mathrm{r}$ & 47.7 g-p & 45.5 \\
\hline Gokturk & $4 \mathrm{~g}-\mathrm{n}$ & $64.7 \mathrm{q}-\mathrm{s}$ & 71.1 & $12.1 \mathrm{a}$ & & 9.6 & 13.6 e-1 & $1 \mathrm{f}-\mathrm{m}$ & 13 & 19.7 h-k & & 20.0 & $38.8 \mathrm{c}-1$ & $42.4 \mathrm{~g}-\mathrm{O}$ & 40.6 & $44.5 \mathrm{~m}-\mathrm{r}$ & $47.0 \mathrm{~h}-\mathrm{r}$ & 45.7 \\
\hline & $.1 \mathrm{~h}-\mathrm{p}$ & $67.6 \mathrm{p}-\mathrm{s}$ & 71.3 & $6.51-p$ & & 6.1 & $12.6 \mathrm{~h}-\mathrm{n}$ & $13.0 \mathrm{~g}-\mathrm{m}$ & 12 & $22.6 b-f$ & $21.5 \mathrm{c}-\mathrm{i}$ & 22.1 & $33.6 \mathrm{~m}-\mathrm{t}$ & $37.0 \mathrm{~g}-\mathrm{o}$ & 35.3 & 43.7 p-r & $47.2 \mathrm{~h}-\mathrm{q}$ & 45.4 \\
\hline & & $62.4 \mathrm{~s}$ & 65.8 & $7.6 \mathrm{~h}-1$ & $6.81-p$ & 7.2 & $13.5 \mathrm{e}-1$ & 12.2 I-o & 12. & $20.9 \mathrm{~d}-\mathrm{j}$ & 19.8 h-k & 20.3 & $40.3 \mathrm{~b}-\mathrm{j}$ & $44.3 \mathrm{ab}$ & 42.3 & $48.2 \mathrm{f}-\mathrm{n}$ & $52.1 \mathrm{c}-\mathrm{f}$ & 50.2 \\
\hline & & $95.0 \mathrm{~b}$ & 100.2 & & & 5.7 & $15.1 \mathrm{~d}-\mathrm{I}$ & & 13 & $21.3 c-j$ & $20.3 \mathrm{f}-\mathrm{k}$ & 20.8 & $37.0 \mathrm{~g}-\mathrm{o}$ & 40.7 b-h & 38.9 & $56.2 \mathrm{ab}$ & $57.4 \mathrm{a}$ & 56.8 \\
\hline & $2 \mathrm{~g}-\mathrm{m}$ & $70.4 \mathrm{~m}-\mathrm{r}$ & 74.3 & $6.71-p$ & $6.01-\mathrm{q}$ & 6.4 & $13.6 \mathrm{e}-1$ & $12.2 \mathrm{I}-\mathrm{O}$ & 12.9 & $23.5 \mathrm{a}-\mathrm{c}$ & $22.4 \mathrm{~b}-\mathrm{g}$ & 22.9 & $38.1 \mathrm{~d}-\mathrm{n}$ & $41.9 \mathrm{~b}-\mathrm{f}$ & 40.0 & $50.3 \mathrm{c}-\mathrm{i}$ & $54.3 \mathrm{a}-\mathrm{c}$ & 52.3 \\
\hline Mean & 80.6 A & 74.4 B & & $9.0 \mathrm{~A}$ & $6.1 \mathrm{~B}$ & & $\begin{array}{ll}13.3 \\
\end{array}$ & 13.0 & & $21.6 \mathrm{~A}$ & 20.6 B & & 39.8 A & $35.5 \mathrm{~B}$ & & $46.5 \mathrm{~B}$ & $49.1 \mathrm{~A}$ & \\
\hline
\end{tabular}

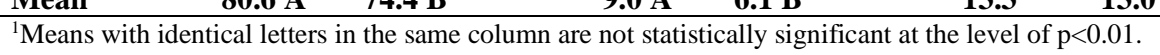


In our study, 1000 seed weight of genotypes varied between 28.9-40.4 g in 2017 and 31.9-46.5 g in 2018 . According to year $\times$ genotypes interactions, the highest 1000 seed weight was Linas in 2017 and GEMO-20 in 2018, while GECE-8 and GEMO-1 genotype had the lowest 1000 seed weight in both years (Table 3). According to Weiss (2000) the 1000 seed weight of safflower seed to increase seed and oil yield must be over $50 \mathrm{~g}$. Unfortunetely, no genotype with a 1000 seed weight greater than $50 \mathrm{~g}$ was determined in either experimental year. The high 1000 seed weights in 2017 might have contributed to high seed and oil yields observed in the first year of the study. Studies have reported that there was a wide variation of 1000 seed weight of safflower. Celikoglu (2004), Camas and Esendal (2006) and Erbas and Baydar (2007) reported that 1000 seeds weight in safflower varies between 33.9-61.7, 19.0-48.0 $\mathrm{g}$ and 33.6$52.1 \mathrm{~g}$, respectively. Although our results were among the variations reported by other studies, genotypes had genetic and environmental differencesAlthough our results are among the variations reported by other studies, genotypes have genetic differences and the environment they which grow in are different. Harvest index of genotypes varied between $8.6-23.9 \%$. The highest harvest index was found in Remzibey-05 (23.9\%), Dincer 5-18-1 (22.7\%) and Balci $(22.2 \%)$ genotypes, while the lowest harvest index was found Centennial (10.9\%), GEMO-23 (10.8\%), GECE-9 (9.5\%) and GEMO-19 (8.6\%) genotypes (Table 4). From studies about the harvest index of safflower plant was obtained different results. Erbas et al. (2016) reported that the harvest index for 39 safflower genotypes ranged between $8.2-29.7 \%$. It is reported that additive alleles were play a more effective role in the inheritance of harvest index in safflower (Golkar and Shahsavari, 2011). Therefore, only selection according to the harvest index may reduce to chances of breeding program success. In our study, there was no differences in the harvest index between the years. The climatic conditions during the growing period in both years affected the growth and seed yields of the plants, but did not affect the harvest index value.

Table 4. Agronomic and quality characteristics, fatty acid compositions of safflower genotypes

\begin{tabular}{|c|c|c|c|c|c|c|c|c|c|c|c|c|}
\hline \multirow{2}{*}{ Genotypes } & \multirow{2}{*}{$\begin{array}{l}\text { Harvest } \\
\text { index }\end{array}$} & \multirow{2}{*}{$\begin{array}{l}\text { Seed } \\
\text { yield }\end{array}$} & \multirow{2}{*}{$\begin{array}{l}\text { Oil } \\
\text { content }\end{array}$} & \multirow{2}{*}{$\begin{array}{l}\text { Oil } \\
\text { yield }\end{array}$} & \multicolumn{2}{|c|}{$\mathrm{C}_{16: 0}$} & \multicolumn{2}{|c|}{$\mathrm{C}_{18: 0}$} & \multicolumn{2}{|c|}{$\mathrm{C}_{18: 1}$} & \multicolumn{2}{|c|}{$\mathrm{C}_{18: 2}$} \\
\hline & & & & & 2017 & 2018 & 2017 & 2018 & 2017 & 2018 & 2017 & 2018 \\
\hline GECE 4 & $18.6 \mathrm{BC}^{1}$ & $136.3 \mathrm{CD}$ & $32.4 \mathrm{C}-\mathrm{E}$ & $44.1 \mathrm{CD}$ & 6.9 & 6.8 & 2.4 & 2.6 & 11.8 & 12.5 & 78.8 & 78.0 \\
\hline GECE 8 & $13.9 \mathrm{FG}$ & $63.9 \mathrm{~K}$ & $35.4 \mathrm{~A}$ & $22.6 \mathrm{~J}$ & 6.5 & 6.3 & 2.8 & 2.4 & 16.5 & 14.5 & 74.2 & 76.4 \\
\hline GECE 9 & $9.5 \mathrm{JK}$ & $68.1 \mathrm{JK}$ & 32.8 B-D & $22.4 \mathrm{~J}$ & 6.3 & 6.6 & 3.3 & 3.6 & 13.5 & 14.3 & 76.9 & 75.2 \\
\hline GECE 11 & $17.2 \mathrm{c}-\mathrm{e}$ & $105.7 \mathrm{fg}$ & $31.0 \mathrm{gh}$ & $32.7 \mathrm{gh}$ & 8.7 & 6.5 & 2.9 & 3.7 & 11.6 & 13.6 & 76.8 & 75.9 \\
\hline GECE 12 & $12.0 \mathrm{hi}$ & $90.8 \mathrm{hi}$ & $32.9 \mathrm{bc}$ & $29.9 \mathrm{hi}$ & 6.3 & 5.4 & 2.1 & 1.9 & 11.5 & 13.7 & 80.1 & 78.9 \\
\hline GEMO 1 & $15.1 \mathrm{e}-\mathrm{g}$ & $114.1 \mathrm{ef}$ & $33.4 \mathrm{~b}$ & $38.1 \mathrm{ef}$ & 7.5 & 7.1 & 3.5 & 2.9 & 12.9 & 13.4 & 76.1 & 76.1 \\
\hline GEMO 3 & $15.4 \mathrm{~d}-\mathrm{f}$ & 117.8 ef & $27.6 \mathrm{k}$ & $32.5 \mathrm{gh}$ & 5.2 & 5.6 & 4.5 & 4.9 & 74.8 & 76.8 & 15.5 & 12.4 \\
\hline GEMO 10 & $18.7 \mathrm{bc}$ & $149.1 \mathrm{bc}$ & $30.4 \mathrm{~h}-\mathrm{j}$ & $45.3 \mathrm{bc}$ & 7.8 & 6.4 & 2.4 & 2.9 & 29.3 & 31.2 & 60.5 & 59.1 \\
\hline GEMO 19 & $8.6 \mathrm{k}$ & $153.5 \mathrm{~b}$ & $33.5 \mathrm{~b}$ & $51.4 \mathrm{a}$ & 4.7 & 6.3 & 3.2 & 2.9 & 44.8 & 41.6 & 47.3 & 49.1 \\
\hline GEMO 20 & $16.0 \mathrm{~d}-\mathrm{f}$ & $120.1 \mathrm{ef}$ & $35.6 \mathrm{a}$ & $42.9 \mathrm{c}-\mathrm{e}$ & 7.1 & 6.7 & 2.8 & 3.3 & 12.7 & 13.4 & 77.4 & 75.9 \\
\hline GEMO 23 & $10.8 \mathrm{i}-\mathrm{k}$ & $95.1 \mathrm{gh}$ & $30.0 \mathrm{ij}$ & $28.5 \mathrm{hi}$ & 5.9 & 6.4 & 2.4 & 2.8 & 23.7 & 25.3 & 68.0 & 65.3 \\
\hline GEMO 28 & $12.9 \mathrm{~g}-\mathrm{i}$ & $157.4 \mathrm{ab}$ & $31.9 \mathrm{~d}-\mathrm{f}$ & $50.3 \mathrm{a}$ & 6.9 & 5.9 & 2.4 & 3.2 & 9.8 & 10.9 & 80.9 & 79.8 \\
\hline GEW6 7 & $14.8 \mathrm{fg}$ & $170.4 \mathrm{a}$ & $31.0 \mathrm{gh}$ & $52.7 \mathrm{a}$ & 7.1 & 7.3 & 3.3 & 2.5 & 13.6 & 14.3 & 76.0 & 75.6 \\
\hline GEW6 16 & $13.6 \mathrm{f}-\mathrm{h}$ & $88.7 \mathrm{hi}$ & $32.2 \mathrm{c}-\mathrm{e}$ & $28.5 \mathrm{hi}$ & 6.9 & 5.4 & 2.4 & 3.1 & 32.5 & 35.6 & 58.2 & 55.3 \\
\hline GEW6 20 & $11.6 \mathrm{~h}-\mathrm{j}$ & 79.7 h-j & $31.2 \mathrm{f}-\mathrm{h}$ & $24.8 \mathrm{ij}$ & 6.5 & 7.3 & 2.4 & 3.2 & 12.7 & 15.3 & 78.4 & 73.4 \\
\hline Dincer 5-18-1 & $22.7 \mathrm{a}$ & $150.0 \mathrm{bc}$ & $29.7 \mathrm{j}$ & $44.5 \mathrm{~b}-\mathrm{d}$ & 7.9 & 6.5 & 2.1 & 2.4 & 11.2 & 13.4 & 78.8 & 77.4 \\
\hline Remzibey-05 & $23.9 \mathrm{a}$ & $128.8 \mathrm{de}$ & $31.9 \mathrm{e}-\mathrm{g}$ & $40.9 \mathrm{c}-\mathrm{f}$ & 6.2 & 5.9 & 1.9 & 2.3 & 13.0 & 14.3 & 78.9 & 77.1 \\
\hline Balci & $22.2 \mathrm{a}$ & $109.6 \mathrm{fg}$ & $35.3 \mathrm{a}$ & 38.7 ef & 6.9 & 6.4 & 1.8 & 1.9 & 13.5 & 15.6 & 77.8 & 75.9 \\
\hline Linas & $13.6 \mathrm{f}-\mathrm{h}$ & $82.6 \mathrm{~h}-\mathrm{j}$ & $35.3 \mathrm{a}$ & $29.1 \mathrm{hi}$ & 6.7 & 6.3 & 2.5 & 2.9 & 12.4 & 14.9 & 78.4 & 75.9 \\
\hline Olas & 19.4 bc & $113.9 \mathrm{ef}$ & $35.7 \mathrm{a}$ & $40.7 \mathrm{c}-\mathrm{f}$ & 6.9 & 6.7 & 1.9 & 2.3 & 21.9 & 25.9 & 69.3 & 65.1 \\
\hline Gokturk & $12.1 \mathrm{hi}$ & $147.0 \mathrm{bc}$ & $33.3 \mathrm{~b}$ & $49.0 \mathrm{ab}$ & 6.6 & 6.9 & 2.1 & 2.7 & 13.1 & 12.9 & 76.2 & 76.9 \\
\hline Centennial & $10.9 \mathrm{i}-\mathrm{k}$ & $78.8 \mathrm{ij}$ & $34.9 \mathrm{a}$ & $27.5 \mathrm{hi}$ & 6.8 & 6.6 & 1.9 & 2.7 & 11.4 & 14.8 & 79.7 & 75.8 \\
\hline W6 9822 & $17.6 \mathrm{~b}-\mathrm{d}$ & 113.9 ef & 31.9 ef & $36.5 \mathrm{fg}$ & 4.8 & 5.3 & 1.7 & 1.8 & 71.9 & 73.4 & 21.2 & 19.4 \\
\hline Gelendost-2 & $14.7 \mathrm{fg}$ & 118.7 ef & 25.71 & $30.4 \mathrm{~h}$ & 6.5 & 6.3 & 2.5 & 2.7 & 11.7 & 10.8 & 78.9 & 80.2 \\
\hline Montola 2000 & $19.8 \mathrm{~b}$ & $128.7 \mathrm{de}$ & $30.8 \mathrm{hi}$ & 39.6 d-f & 6.2 & 6.4 & 2.3 & 2.9 & 69.3 & 67.4 & 21.9 & 23.1 \\
\hline
\end{tabular}

${ }^{1}$ Means with identical letters in the same column are not statistically significant at the level of $\mathrm{p}<0.01$.

The average seed yields of genotypes were found to be higher in 2017 due to greater rainfall from the seed sowing to the budding period (206 $\mathrm{mm}$ in 2017 and 138.6 $\mathrm{mm}$ in 2018). Among the genotypes, the highest seed yield was found in GEW6-7 genotype (170.4 $\left.\mathrm{kg} \mathrm{da}^{-1}\right)$ and the lowest seed yield was found in GECE-8 genotype (63.9 $\mathrm{kg} \mathrm{da}^{-1}$ ) (Table 4). In the world, $40-170 \mathrm{~kg} \mathrm{da}^{-1}$ of seed yield could be obtained from safflower in arid areas, but up to $300 \mathrm{~kg} \mathrm{da}^{-1}$ of seed yield can be obtained under favorable cultivation areas (Weiss, 2000). In the studies, the seed yield from different safflower genotypes carried out in different arid areas in Turkey varied between 207.7$339.7 \mathrm{~kg} \mathrm{da}^{-1}$ in Eskisehir (Celikoglu, 2004), 77.4-167.8 $\mathrm{kg} \mathrm{da}^{-1}$ in Erzurum (Ozturk et al., 2008), and 45.6-298.0 $\mathrm{kg} \mathrm{da}^{-1}$ in Samsun (Camas and Esendal, 2006). However, it was reported that even in the ecology of Isparta where this experiment is carried out, seed yield may differ in the safflower. It has been reported that seed yield varies between 84.9-163.0 kg da ${ }^{-1}$ in $F_{5}$ lines derived from crossing Dincer 5-118 $\times$ Remzibey-05 safflower varieties 
(Erbas and Baydar, 2007); 119.5-460.7 $\mathrm{kg} \mathrm{da}^{-1}$ in $\mathrm{F}_{1}$ population, 22.7-635.6 kg da-1 in $\mathrm{F}_{2}$ population (Erbas, 2012), 26.0-353.0 kg da ${ }^{-1}$ in $F_{3}$ population and 74.5$225.3 \mathrm{~kg} \mathrm{da}^{-1}$ in $\mathrm{F}_{4}$ population (Baydar and Erbas, 2014) derived from crossing Dincer 5-118 $\times$ Montola 2000 safflower varieties. On the other hand, Erbas and Baydar (2011) and Erbas et al. (2016) reported that seed yield of safflower ranged between 79.7-190.7 $\mathrm{kg} \mathrm{da} \mathrm{da}^{-1}$ in 9 genotypes and $15.2-215.9 \mathrm{~kg} \mathrm{da}^{-1}$ in 39 genotypes, respectively.

The hull contents of the lines and cultivars varied from $43.0 \%$ to $57.4 \%$. Genotypes had higher hull content in 2018. The main reason for this may be that the plants could not fill the seed during the maturing period because the plants produced higher head number, but had low seed yield and 1000 seed weight in this year. Gelendost-2 was to the highest hull content in both years. Similarly, in the second year of the experiment, the Montola 2000 genotype was to the high hull content. GEMO-1, 19, GEW6-16 and Gokturk had the lowest hull content in both years (Table 4). Rudra Naik et al. (2009) reported that the environment may have an impact on the hull content in safflower, but the variation is mostly due to genetic factors. In our study, the differences of hull content between the years may be slightly due to environmental impact. In other studies, similar results were obtained for hull content in safflower (Adali and Ozturk, 2016; Erbas et al., 2016). One of the most important goals in safflower breeding is to increase the oil content and to reach the optimum level with seed and oil yield. The oil contents of the genotypes varied between 25.7 and $35.7 \%$ on average in the study. According to the two-year averages of the genotypes, Olas (35.7\%), GEMO-20 (35.6\%), GECE-8 (35.4\%), Balci $(35.3 \%)$, Linas $(35.3 \%)$ and Centennial (34.9\%) genotypes had the highest oil content, Gelendost2 genotype has the lowest oil content (Table 4). As a matter of fact, it has been emphasized by researchers that the oil content of safflower has moderate and high inheritance, but is controlled by alleles with few additive effects (Ramachandram and Goud, 1981). In many studies, similar variations for the oil content of safflower obtained from different safflower genotypes in different regions in Turkey varied by 19.8-39.8\% (Celikoglu, 2004; Beyyavas et al., 2010; Ada, 2012).

In our study, the oil yield of the lines with high seed yield was found to be high. Oil yield of GEW6-7, GEMO19 and GEMO-28 genotypes showed superior performance than other cultivars, except for Gokturk. On the other hand, the lowest oil yield was determined in GEW6-20, GECE-8 and GECE-9 genotypes (Table 4). In safflower farming, cultivars with the highest oil yield per unit area are preferred. Thus, both high of seed yield and oil content is being worked on to develop cultivars. In other studies, oil yield in safflower varied according to locations. Beyyavas et al. (2010) in Sanliurfa conditions and Ada (2012) in Konya conditions reported variation in oil yield between 24.2-54.3 $\mathrm{kg} \mathrm{da}^{-1}$ and 14.4-108.1 $\mathrm{kg} \mathrm{da}^{-1}$, respectively. In previous studies conducted under Isparta conditions, it has been reported that oil yield varies in safflower plants (Erbas and Baydar, 2007; Erbas, 2012; Baydar and Erbas, 2014; Erbas et al., 2016). Oil yield differences in our study were due to the use of materials with different genetic structure as well as climatic differences.

The fatty acid composition of safflower genotypes in 2017 and 2018 was presented in Table 5. The palmitic, stearic, oleic and linoleic acid content of genotypes varied between $4.7-8.7,1.7-4.5,9.8-74.8$ and $15.5-80.9 \%$ in 2017; 5.3-7.3, 1.9-4.9, 10.8-76.8 and $12.4-80.2 \%$ in 2018, respectively. In both years, while Gelendost-2 and Centennial had high linoleic content, Montola 2000 and W6 9822 had high oleic content. The oleic acid content of GEMO-3 was 74.8 and $76.8 \%$ in 2017 and 2018, respectively. On the other hand, GEMO-10, 19 and 23 and GEW6-16 were in the middle oleic acid group. The highest linoleic acid content was determined in the GECE12 and GEMO-28 lines according to the average of both years (Table 5). No significant difference was observed in the fatty acid contents of the lines by years. FernadezMartinez et al. (1993) stated thatthe oleic (3.1-90.6\%) and linoleic (3.9-88.8\%) acids contents of 200 different safflower genotypes from 37 countries were different. Liu et al. (2016) reported that in their adaptation study, with 21 safflower cultivars from 12 countries, oil content was 9.1-25.1\%, palmitic acid content was $4.0-7.9 \%$, stearic acid $1.5-2.8 \%$, oleic acid $7.9-33.0 \%$ and linoleic acid $62.7-83.7 \%$. Our results were in compliance with the results of the researchers mentioned above and within the limits of the variation mentioned.

In recent years, despite the changes shown in production areas and quantities of the safflower in Turkey, safflower is trying to find a place in Turkish agriculture with the support of the state. Because of high seed and oil yield and different fatty acids composition in the safflower new cultivars have been gained. In our study, the lines with especially low hull content and high 1000 seed weight, oil content, seed and oil yield were determined. GECE-8 and GEMO-20 lines for high oil content, GEMO19, GEMO-28 and GEW6-7 for oil yield, GEMO-28 and GEW6-7 for seed yield and GEMO-20 for 1000 seed weight are superior to the varieties and in the same statistical group. GEMO-3, which has the highest oleic acid content, was found to low oil content, seed and oil yield. As a result; GEMO-19, GEMO-20, GEMO-28 and GEW6-7 can be selected as cultivar candidate.

\section{ACKNOWLEDGEMENTS}

This study is master thesis of the first author (EA).

\section{LITERATURE CITED}

FAOSTAT, 2020. http://www.fao.org/faostat/en/\#data/QC. (accesed date: 10.01.2020)

BYSD, 2020. http://www.bysd.org.tr/Dis TicaretRakamlari/. (accesed date: 10.01.2020).

Anonymous, 2020. Turkish State Meteorological Service. (https://mgm.gov.tr/).

Ada, R. 2012. E ffects of winter and spring sowing on yield components of safflower genotypes. International Journal of Agricultural and Biosystems Engineering 6(6): 1-5. 
Adali, M. and O. Ozturk. 2016. Determination of yield and some yield components of safflower of Konya conditions. Journal of Selcuk Agricultural Sciences 3(2): 233-237.

Baydar, H., S. Erbas, H. Hatipoglu and H. Koc 2011. Adaptation and stability analyses of safflower (Carthamus tinctorius L.) lines developed by cross-breeding. 4. Turkey Seed Congress, 14-17 June 2011, Samsun, 1: 53-62 (in Turkish).

Baydar, H. and S. Erbas. 2014. Technologies and Sciences of Oil Crops. SDU Press, Isparta, Turkey.

Baydar, H. and S. Erbas. 2016. Line development breeding for high yield, oil and oleic acid content in safflower (Carthamus tinctorius L.). Journal of Field Crops Central Research Institute. 25(Special issue-2):155-161 (in Turkish).

Beyyavas, V., H. Haliloglu, O. Copur and A. Yilmaz. 2010 Determination of seed yield and yield components of some safflower (Carthamus tinctorius L.) cultivars, lines and populations under the semi-arid conditions. African J. Biotech. 10(4):527-534.

Camas, N. and E. Esendal. 2006. Estimates of broad-sense heritability for seed yield and yield components of safflower (Carthamus tinctorius L.). Hereditas. 143:55-57.

Celikoglu, F. 2004. Determination of yield characters of some safflower (Carthamus tinctorius L.) lines under Eskisehir conditions. MS Thesis, Ankara University.

Deokar, A.B.S. and F.B. Patil. 1980. Analysis of parameters of variability in some Indian varieties of safflower. Field Crop Abstracts 33(1): 536.

Erbas, S. and H. Baydar. 2007. Possibilities of the line development from the hybrid populations obtained by synthetic male sterility technique in safflower (Carthamus tinctorius L.). 8. Turkey Field Crops Congress, 25-27 June 2007, Erzurum, 1: 370-374 (in Turkish).

Erbas, S. and H. Baydar. 2011. Estimates of broad-sense heritability for agronomic and quality characters of safflower (Carthamus tinctorius L.) line and parents. 9. Turkey Field Crops Congress, 12-15 September 2011, Bursa, 1027-1032 (in Turkish).

Erbas, S. 2012. Development of safflower (Carthamus tinctorius L.) lines with high oil, oleic acid content and seed yield through hybridization breeding. $\mathrm{PhD}$ Thesis, Suleyman Demirel University.
Erbas, S., M. Tonguc and A. Sanli. 2016. Variations in the agronomic and quality characteristics of domestic and foreign safflower (Carthamus tinctorius L.) genotypes. Turkish Journal Field Crops 21(1):110-119.

Fernandez-Martinez, J., M. Del Rio and A. De Haro. 1993. Survey of safflower (Carthamus tinctorius L.) germplasm for variants in fatty acid composition and seed characters. Euphytica 69:115-122.

Golkar, P. and M.R. Shahsavari. 2011. Genetic analysis of harvest index in safflower (Carthamus tinctorius L.) via diallel crosses. Res. Plant Biol. 1(3):43-47.

Liu, L., L. Guan and Y. Yang. 2016. A review of fatty acids and genetic characterization of safflower (Carthamus tinctorius L.) seed oil. World J. Tradit. Chin. Med. 2(2):48-52.

Marquard, R. 1987. Qualitatsanalytik Im Dienste der Olpflanzenzuchtung. Fat. Sci. Technol. 89:95-99.

Ozturk, E., H. Ozer and T. Polat. 2008. Growth and yield of safflower genotypes grown under irrigated and non-irrigated conditions in a highland environment. Plant Soil Environment 54(10):453-460.

Parameshwar, K.B. 2009. Stability of non-spiny breeding lines in safflower (Carthamus tinctorius L.). Department of Genetics and Plant Breeding College of Agriculture. MS Thesis, Dharwad University of Agricultural Sciences.

Ramachandram, M. and J.V. Goud. 1981. Genetic analysis of seed yield, oil content and their components in safflower (Carthamus tinctorius L.). Theor. Appl. Genet. 60:191-195.

Rowell, D.L. 1996. Soil Science: Methods and Applications. Longman. London.

Rudra Naik, V., G.M. Bentur, P.M. Salimath and K.G. Parameshwarappa. 2009. Introgression of non spiny and high oil content in adapted generations of safflower (Carthamus tinctorius L.). Karnataka J. Agric. Sci. 22(1):39-43.

SAS Institute, 1999. INC SAS/STAT User's Guide Release 7.0 Cary NC, USA.

Singh, V., N.M. Kolekar and N. Nimbkar. 2008. Breeding strategy for improvement of flower and seed yields in safflower. $7^{\text {th }}$ Int. Safflower Conf. New South Wales, Australia.

Weiss, E.A. 2000. Oilseed Crops. $2^{\text {nd }}$ Edition, Blackwell Sci. Ltd. Victoria, Australia. 